\title{
Surviving the effects of barotrauma: assessing treatment options and a 'natural' remedy to enhance the release survival of line caught pink snapper (Pagrus auratus)
}

\author{
M. F. MCLENNAN, M. J. CAMPBELL \& W. D. SUMPTON \\ Queensland Department of Agriculture Fisheries and Forestry, Brisbane, Qld, Australia
}

\begin{abstract}
A new technique to ameliorate the effects of barotrauma was tested based on observations of pink snapper, Pagrus auratus (Forster), inadvertently piercing their everted stomach with their teeth and releasing trapped swim bladder gases. This technique was termed buccal venting and involved piercing the everted stomach protruding into the buccal cavity or out of the mouth with a 16-gauge hypodermic needle (a practice previously not encouraged). Short-term ( $\sim 3$ days) survival of buccal-vented fish was not significantly different from laterally vented fish nor untreated controls. Both buccal and lateral venting techniques were shown to cause no harm and allowed fish to return to depth. The short-term (1-3 days) post-release survival of line caught snapper was $88 \%$ with no significant difference in survival across three depth ranges tested (37-50, 51-100 and 101-180 m). Survival of sublegal pink snapper $(<35 \mathrm{~cm} \mathrm{TL})$ was not significantly different $(P>0.05)$ from that of legal-sized fish $(\geq 35 \mathrm{~cm}$ TL). Healing of the swim bladder was observed in $27 \%$ of pink snapper dissected after $\leq 3$ days in captivity, and healing of stomachs was observed in $64 \%$ of pink snapper that had been buccal vented. Relatively high post-release survival rates of line caught pink snapper may offer some protection for snapper stocks where high fishing pressure and legal size restrictions result in the majority of the catch having to be released.
\end{abstract}

K E Y W O R D S : $\quad$ angling, buccal, discard mortality, stomach, swim bladder, venting.

\section{Introduction}

Many studies have looked at various ways of increasing the post-release survival of fish caught via hook and line. Low rates of post-release survival for line caught fish have been attributed to a wide range of factors including hook size, hook type and hooking location (Cooke et al. 2003; Butcher et al. 2007; Wilde \& Sawynok 2009; Grixti et al. 2010; McGrath et al. 2011; Broadhurst et al. 2012), handling, surface interval, depth of capture and barotrauma (McLeay et al. 2002; Bartholomew \& Bohnsack 2005; Danylchuk et al. 2007; Brown et al. 2010; Butcher et al. 2012). The effects of barotrauma can sometimes be ameliorated by employing barotrauma relief measures such as using a heavy weight to return fish to depth (variously termed a 'shot release' or 'deepwater release mechanism') and lateral venting, which have been investigated for a wide range of species with mixed results (St John \& Syers 2005; Wilde 2009;
Brown et al. 2010; Hochhalter \& Reed 2011; Butcher et al. 2012). Wilde (2009) postulated that lateral venting may reduce the survival of fish, particularly those taken in deeper waters. However, other studies have shown that the benefits of lateral venting can be species specific (Burns \& Restrepo 2002; Brown et al. 2008).

In this study, a new venting technique (termed 'buccal venting') to ameliorate the effects of barotrauma was trialled. This was based upon in situ observations of hookand-line caught pink snapper Pagrus auratus (Forster), biting down and piercing the gut protruding into the buccal cavity as a result of barotrauma. The subsequent release of the expanded swim bladder gases trapped within the body cavity allowed fish to return to depth in the same manner as fish that had been laterally vented. However, survival information of these fish has not been available.

The ability of a fish to survive the effects of barotrauma depends on the physical damage caused by the initial trauma, subsequent treatment and by its capacity to heal 
the damage to affected organs. Studies have reported healing of swim bladders occurring within very short time frames $(<24$ h) (Shasteen \& Sheehan 1997; Burns \& Restrepo 2002; Nichol \& Chilton 2006; Bellgraph et al. 2008; Midling et al. 2012; Humborstad \& Mangor-Jensen 2013; Campbell et al. 2014). By contrast, a search of the literature failed to find any information on the effects of piercing the everted gut of fish.

Regardless of whether discard mortality results from physical injury through hook damage, poor handling or barotrauma (and resultant treatments), it can contribute significantly to fishing mortality and, as such, should be factored into resource assessments (St John \& Syers 2005; Cooke \& Schramm 2007). Estimates of discard mortality equal to or greater than the landed catch have been reported for many line caught species (Broadhurst et al. 2005; Butcher et al. 2008; Campana et al. 2009; Brown et al. 2010; Ferter et al. 2013). High levels of discarding and low survival rates of released fish have the potential to reduce the effectiveness of conservation measures such as in-possession ( bag) limits and minimum legal sizes.

In Queensland, the pink snapper fishery is predominantly an offshore hook-and-line fishery with a high proportion of the catch taken in waters $>30 \mathrm{~m}$ (Sumpton et al. 2003), where barotrauma is likely to occur. Pink snapper are managed via a number of input and output controls including restrictions on the number of hooks used as well as minimum legal size ( $35 \mathrm{~cm} \mathrm{TL}$ ) and bag limits. Recreational discard rates of this species in Queensland are between 57\% and 76\% (Higgs 1999, 2001; McInnes 2006, 2008), and recent stock assessments evaluated this stock as overfished (Allen et al.
2006; Campbell et al. 2009). These analyses used estimates of discard mortality ranging from $40 \%$ to $70 \%$ based on previous studies for discarded pink snapper (Stewart 2008; St John et al. 2009), which suggests considerable impact of discard mortality on pink snapper stocks.

The primary objective of the current study was to assess buccal venting as an alternative venting technique; secondly, to evaluate the effects of barotrauma relief method, water depth and fish size on the short-term ( $\sim 3$ days) survival of line caught pink snapper and, thirdly, to provide more accurate estimates of short-term post-release survival.

\section{Materials and methods}

\section{Study site and data collection}

Fish were captured from a range of depths (37-180 m) in the offshore waters of south-east Queensland. Capture sites at Double Island Point (Fig. 1, map a) ranged in depth from 37 to $50 \mathrm{~m}$, whilst depths at the sites north of Cape Moreton (Fig. 1, map b) ranged from 51 to $180 \mathrm{~m}$.

The experiments carried out at Double Island Point used the 15-m deep vertical enclosures described by Brown et al. (2010) and Campbell et al. (2014). Pink snapper were caught by hook-and-line using conventional rod-and-reel outfits typical of recreational and commercial line fishers. These were spooled with 20 $30 \mathrm{~kg}$ breaking strain braided line attached to $20-30 \mathrm{~kg}$ breaking strain monofilament paternoster rigs with two separate J-style 5/0 Mustad Big Red hooks (O. Mustad \& Son A.S., Gjövik, Norway) attached via the branching

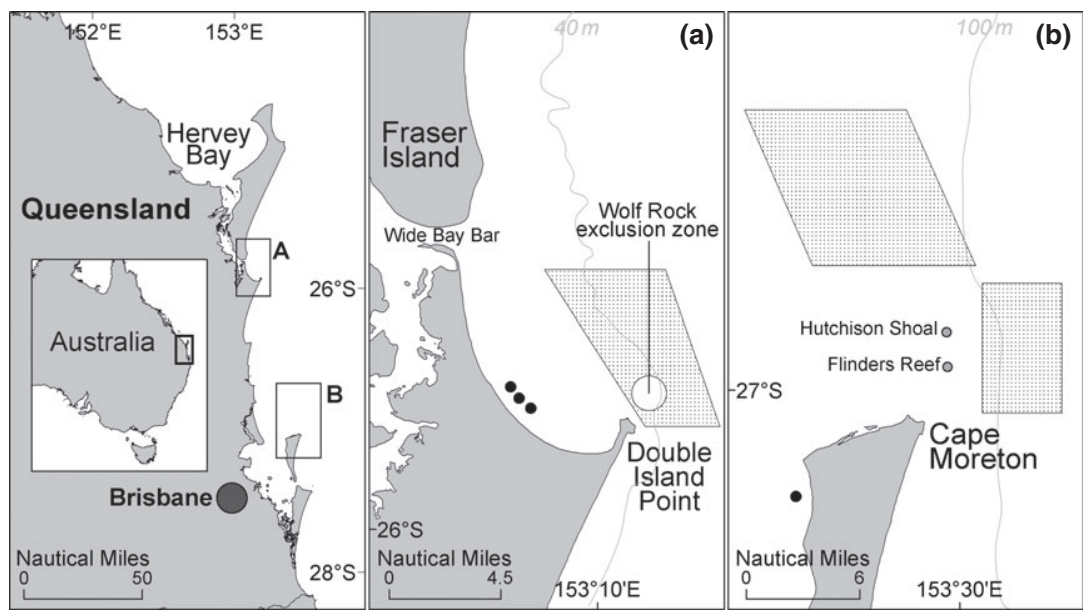

Figure 1. Location of post-release survival experiments. (a) The Double Island Point area was the location for the shallow ( $\leq 50 \mathrm{~m})$ experiments; (b) the Moreton Island area was the location of the deeper $(>50 \mathrm{~m})$ experiments. The black circles represent the location of the vertical enclosures when used, and the shaded areas represent the fishing grounds. 
lines and a lead sinker of between 110 and $450 \mathrm{~g}$, dependent upon depth and current, attached at the bottom. Upon capture, all pink snapper over $20-\mathrm{cm}$ total length were tagged with a uniquely numbered HallPrint $^{\mathrm{TM}}$ (Hallprint Pty. Ltd., Hindmarsh Valley, Australia) T-bar tag $(75 \times 2 \mathrm{~mm})$ and retained. The $20-\mathrm{cm}$ size limit ensured smaller fish did not escape through or become enmeshed in the 101-mm mesh walls of the enclosures. The catch was placed in one of two 1.4-t holding tanks $(1.2 \mathrm{~m}$ high $\times 1.3 \mathrm{~m}$ diameter $)$ with $250 \mathrm{~L} \mathrm{~min}^{-1}$ seawater flow-through systems on-board the Fisheries Research Vessel Tom Marshall, a 14-m catamaran. Details recorded included the following: angler; time of capture; fork length $(F L)$; barotrauma symptoms (none, bloating, gut extrusion, exophthalmia); bleeding (none, slight, severe); injury (no damage, hooked in eye, gill damage, jaw damage, moderate scale loss, heavy scale loss); hook location (lip, mouth, gut, outside); treatment (none, lateral vent, buccal vent, self-buccal vent); vertical enclosure identification; release condition (1-5 as per Brown et al. 2010); and release time into vertical enclosure. Where gut hooking occurred, the line was cut and the hook left in situ. Surface interval, the time between capture and release into the enclosures, was kept to a minimum.

Lateral venting was conducted in the manner recommended by the Florida Sea Grant Program (2005). Fish were buccal vented using the same size hypodermic needle $(38 \mathrm{~mm} \times 16$ gauge) used in the traditional lateral venting treatment. Buccal venting was also recorded when the stomach was accidently pierced with the hook point during extraction, whilst any fish that pierced the everted gut with its teeth were classified as 'self-buccal' vented. Fish that displayed barotrauma symptoms, excluding those that were treated as self-buccal vented, were assigned a treatment (vented, buccal vented or control) in the order they came aboard.

Once the first fish caught had been held for $45 \mathrm{~min}$, all fish were transferred to the vertical enclosures via the Fisheries Research Vessel Makaira, a 5.8-m Centre Cab powerboat. On the fourth day of the experiments at Double Island Point, the vertical enclosure containing fish from the first day's fishing was retrieved and all fish assessed for vitality. This procedure was then repeated on subsequent days until all the vertical enclosures had been retrieved.

Due to logistical considerations such as wind, swell, current, distance to protected waters from fishing grounds and shipping traffic, the standard vertical enclosures could not be used at the deeper catch sites offshore from Moreton Island (Fig. 1, map b). During these trips, experimental protocols remained the same except that pink snapper were kept on-board in the flow-through tanks mentioned above or placed in a standard vertical enclosure modified to hang at to a depth of $5 \mathrm{~m}$. Fish were kept on-board throughout the day and transferred to the vertical enclosure at the cessation of fishing.

At the termination of all experiments, fish were recovered and their tag number, condition and vitality (dead or alive) recorded. All surviving fish were then euthanised by pithing as per Queensland Department of Employment, Economic Development and Innovation animal ethics approval reference number CA2009/02/333 and, along with any fish that had already died, frozen for subsequent dissection in the laboratory.

For all fish dissected, the size and position of all perforations in the swim bladder, and signs of healing were recorded. In addition, pressure was applied to the gut area, whilst fish were submerged to establish if gases could have escaped from the anal vent during ascent. Swim bladders that appeared to have healed were injected with water to further test whether healing had occurred. The stomachs were examined for perforations, any signs of healing or infection and whether they had returned to a normal position within the body cavity. If the stomach appeared to have healed, it was removed and injected with water from a syringe to ascertain whether healing had occurred.

\section{Data analysis}

Statistical analysis was carried out using generalised linear modelling (GLM) in GenStat (2011) via a binomial distribution and logit link function, where vitality $(0=$ dead, $1=$ alive $)$ was the response variable. Depths were transformed from a continuous variable to a categorical variable with three levels, shallow $(\leq 50 \mathrm{~m})$, moderate $(51-100 \mathrm{~m})$ and deep (101-180 m), whilst fish length was categorised into either sublegal $(<35 \mathrm{~cm})$ or legal $(\geq 35 \mathrm{~cm})$. Other factors included in the model were as follows: signs of barotrauma (none, exophthalmia, stomach protruding into the buccal cavity or out of the mouth, swollen abdomen); bleeding (yes, no); hook location (lip, mouth, throat, gut, outside or foul hooked); injury (none, eye, gill damage, jaw damage, moderate scale loss, heavy scale loss). The effect of the enclosure type (15-m deep enclosure, 5-m deep enclosure, on-board tanks) on post-release survival was also quantified, as was the effect of two continuous variables, surface interval (in minutes) and time in captivity (in hours). Experiment number (1-6) was also included in this model to assess any spatial and temporal variability in post-release survival. The GenStat RSEARCH function was used to determine the final model via forward elimination.

A second GLM analysis was conducted with removal from the data set of pink snapper showing no symptoms 
of barotrauma upon capture, to determine whether barotrauma treatment method (vented, buccal vented, self-buccal vented and control) affected the post-release survival of pink snapper using the factors described above via a binomial distribution and logit link function.

A third GLM was used to test the effects of the above factors on the presence/absence of healing of swim bladder perforations, whilst the effects of the above factors on the size of swim bladder perforations were quantified using a GLM via a normal distribution and identity link function.

Where a factor was found to be significant $(P<0.5)$ in the GLM analyses, the difference between levels of this factor was tested using pairwise $t$-tests in GenStat via the RPAIR function. Where a marginally significant effect occurred, the sample size required to detect a significant difference was determined using the SBNTEST function in GenStat with the power of the test set at $80 \%$.

\section{Results}

\section{Overall post-release survival}

A total of 267 pink snapper were caught during six trips conducted from August 2009 to August 2012. Overall, post-release survival for pink snapper caught in this study was $88 \%$. External barotrauma symptoms were present in $77 \%$ of pink snapper caught across all depth classes. In some instances, bubbles were observed rising to the surface as fish were being angled, suggesting that swim bladder gases had escaped the gut cavity, resulting in individuals presenting with no external barotrauma symptoms. These fish were included in the analysis of overall survival but excluded from the analysis of the effect of barotrauma relief treatments as these individuals were not treated (Table 1). Size of fish and depth of capture did not significantly $(P>0.05)$ affect survival (Fig. 2).

Bleeding significantly $(P<0.05)$ reduced survival to $66 \%$ compared with $88 \%$ for those fish where bleeding did not occur (Table 2). Further, hooking location was found to affect post-release survival significantly $(P<0.05)$, with 4 of the $5(\sim 2 \%$ of catch) gut-hooked fish dying.

\section{Effect of barotrauma relief treatment on post-release survival}

There was no significant difference $(P>0.1)$ in survival between fish that were buccal vented and those that selfbuccal vented at capture. As such, survival data from these two treatments were pooled and fish analysed
Table 1. Observed number of pink snapper (Pagrus auratus) in each factor and level and the resultant observed survival during experimental trials

\begin{tabular}{|c|c|c|c|c|c|}
\hline Factor & Level & Survived & Died & Total & $\begin{array}{c}\% \\
\text { Survival }\end{array}$ \\
\hline \multirow[t]{4}{*}{ Treatment } & Buccal/self-vent & 77 & 4 & 81 & 95 \\
\hline & Lateral vent & 57 & 12 & 69 & 83 \\
\hline & None & 46 & 7 & 53 & 87 \\
\hline & No symptom* & 55 & 8 & 63 & 87 \\
\hline \multirow[t]{3}{*}{ Depth class } & Shallow $(37-50 \mathrm{~m})$ & 122 & 13 & 135 & 90 \\
\hline & $\begin{array}{l}\text { Moderate } \\
\quad(51-100 \mathrm{~m})\end{array}$ & 36 & 6 & 42 & 86 \\
\hline & Deep $(101-180 \mathrm{~m})$ & 22 & 4 & 26 & 85 \\
\hline \multirow[t]{2}{*}{ Size } & Legal $(\geq 35 \mathrm{~cm} \mathrm{TL})$ & 42 & 9 & 51 & 82 \\
\hline & $\begin{array}{l}\text { Sublegal } \\
(<35 \mathrm{~cm} \mathrm{TL})\end{array}$ & 138 & 14 & 152 & 91 \\
\hline \multirow{6}{*}{$\begin{array}{l}\text { Depth } \times \\
\text { size }\end{array}$} & Shallow $\times$ legal & 10 & 4 & 14 & 71 \\
\hline & Moderate $\times$ legal & 20 & 2 & 22 & 91 \\
\hline & Deep $\times$ legal & 12 & 3 & 15 & 80 \\
\hline & $\begin{array}{c}\text { Shallow } \times \\
\text { sublegal }\end{array}$ & 112 & 9 & 121 & 93 \\
\hline & $\begin{array}{l}\text { Moderate } \times \\
\text { sublegal }\end{array}$ & 16 & 4 & 20 & 80 \\
\hline & $\begin{array}{l}\text { Deep } \times \\
\text { sublegal }\end{array}$ & 10 & 1 & 11 & 91 \\
\hline \multirow[t]{2}{*}{ Bleeding } & Yes & 9 & 6 & 15 & 60 \\
\hline & No & 230 & 24 & 254 & 91 \\
\hline
\end{tabular}

* Fish not included in the analysis of treatment as they showed no barotrauma symptoms.

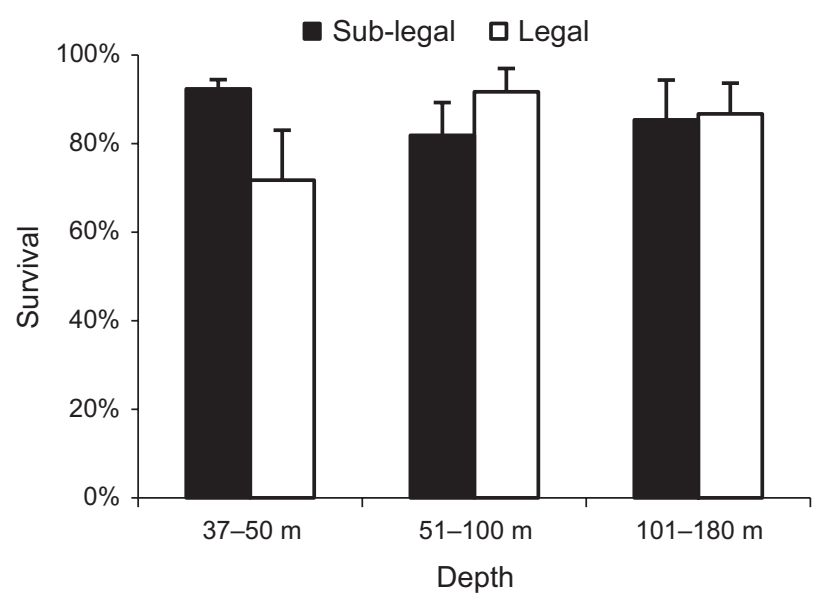

Figure 2. Adjusted survival of pink snapper as a function of the size/ depth class interaction. Error bars standard errors from the generalised linear modelling (GLM).

further as buccal vented. Whilst treatment was found to be a significant factor affecting survival (Table 3), subsequent pair-wise $t$-tests showed no significant $(P>0.05)$ difference between treatments. However, a slight trend towards lower survival in fish that were laterally vented, compared to buccal-vented fish, was observed 
Table 2. Accumulated analysis of deviance table from the binomial generalised linear modelling (GLM) assessing various factors affecting short-term (1-3 days) post-release survival of pink snapper

\begin{tabular}{lrrrrr}
\hline \multicolumn{1}{c}{ Factor } & d.f. & Deviance & $\begin{array}{c}\text { Mean } \\
\text { deviance }\end{array}$ & $\begin{array}{c}\text { Deviance } \\
\text { ratio }\end{array}$ & $\chi^{2}$ prob. \\
\hline Bleeding & 1 & 7.92 & 7.91 & 7.91 & 0.005 \\
Hook location & 3 & 11.89 & 3.96 & 3.96 & 0.008 \\
Treatment & 2 & 5.26 & 2.63 & 2.63 & 0.072 \\
Size & 1 & 1.54 & 1.54 & 1.54 & 0.214 \\
Depth class & 2 & 2.02 & 1.01 & 1.01 & 0.364 \\
Residual & 257 & 153.26 & 0.60 & & \\
Total & 268 & 188.13 & 0.70 & & \\
\hline
\end{tabular}

Size is a categorical variable where fish were categorised as sublegal ( $<35 \mathrm{~cm} \mathrm{TL}$ ) and legal $(\geq 35 \mathrm{~cm} \mathrm{TL})$. Depths were categorised as shallow (37-50 m), moderate (51-100 m) and deep (101-180 m).

Table 3. Accumulated analysis of deviance table with data for novisible-symptom fish removed from data set

\begin{tabular}{|c|c|c|c|c|c|}
\hline Factor & d.f. & Deviance & $\begin{array}{c}\text { Mean } \\
\text { deviance }\end{array}$ & $\begin{array}{l}\text { Deviance } \\
\text { ratio }\end{array}$ & $\chi^{2}$ prob. \\
\hline Bleeding & 1 & 7.31 & 7.31 & 7.31 & 0.007 \\
\hline Hook location & 3 & 10.70 & 3.57 & 3.57 & 0.013 \\
\hline Treatment & 2 & 6.84 & 3.42 & 3.42 & 0.033 \\
\hline Size & 1 & 3.64 & 3.64 & 3.64 & 0.056 \\
\hline Depth class & 2 & 0.41 & 0.20 & 0.20 & 0.816 \\
\hline Residual & 196 & 127.31 & 0.65 & & \\
\hline Total & 205 & 156.20 & 0.76 & & \\
\hline
\end{tabular}

The binomial generalised linear modelling (GLM) assessed various factors affecting short-term ( $\leq 3$ days) post-release survival of pink snapper. Size is a categorical variable where fish were categorised as sublegal $(<35 \mathrm{~cm} \mathrm{TL})$ and legal $(\geq 35 \mathrm{~cm} \mathrm{TL})$. Depths were categorised as shallow $(37-50 \mathrm{~m})$, moderate $(51-100 \mathrm{~m})$ and deep $(101-180 \mathrm{~m})$.

$(P=0.095)$. A power analysis of these data suggested that a sample size of 189 individuals for each treatment would be required to detect significant difference at the $95 \%$ confidence level and power of the test set at $80 \%$.

\section{Effects of capture on the swim bladders and stomachs of pink snapper}

Swim bladders were observed to have healed in $55 \%$ of the pink snapper kept in the shortened vertical enclosure and $45 \%$ of pink snapper kept in the flow-through tanks, whereas observed healing rates for pink snapper kept in the 15-m-deep vertical enclosures were much lower (19\%). Sixty percent of ruptures of the swim bladder occurred at the rete mirabile, $22 \%$ occurred halfway along the length of the swim bladder, $8 \%$ of ruptures occurred in the posterior half of the swim bladder, whilst the remaining $10 \%$ of ruptures occurring anterior of the rete mirabile. The size of the rupture was significantly larger $(P<0.05)$ for fish taken in the moderate and deep depth classes, and larger ruptures were less likely to have healed. Intact swim bladders occurred in only $3 \%$ $(n=7)$ of pink snapper.

For pink snapper that exhibited stomach prolapse, the dissections revealed that the stomach was in a normal position within the gut cavity for $56 \%$ when buccal vented, $78 \%$ when laterally vented and $65 \%$ for controls. Pink snapper that were not laterally vented (buccal, self and no treatment) often had stomachs that were slightly inverted and clenched around the site of any wound in the stomach. The stomachs of pink snapper that were buccal vented (including those that self-buccal vented) were found to have healed in $64 \%$ of cases. Two fish that had not been buccal-vented displayed healed wounds to the stomach similar to those of buccal-vented fish. Signs of infection were found in only $4 \%(n=3)$ of the buccal-vented fish when dissected. Of the fish dissected, 19\% showed air bubbles from the anal vent when pressure was applied to the gut area of a submerged fish.

\section{Discussion}

Benefits of laterally venting fish suffering barotrauma have been shown to be species specific with fish captured from the same locations and depth exhibiting very different barotrauma symptoms and responses to venting (Collins et al. 1999; Burns \& Restrepo 2002). Brown et al. (2008) found an increase in short-term survival for Lutjanus malabaricus (Bloch and Schneider) but not for Lutjanus erythropterus (Bloch) when vented. Individuals of these two species were captured from the same depth at the same site in mixed schools but exhibited significant differences in barotrauma-related injury, response to lateral venting and subsequent survival. Lutjanus malabaricus had a significantly higher survival when vented but had a lower overall survival than its congener L. erythropterus. Lateral venting is not universally acknowledged as a useful treatment for barotrauma (Wilde 2009) as the technique can puncture organs other than the swim bladder and causes other injuries due to extended handling (Kerr 2001). Agencies in both Australia (Recfishing Australia 2013) and the USA (National Marine Fisheries Service 2013) now advocate the use of various forms of cages or weights to return fish to capture depth with lateral venting as a second option.

In this study, no significant differences were found in the survival of fish that were either buccal or laterally vented and survival of treated fish did not differ from control fish. However, vented fish were able to regain correct orientation in the tanks and return to depth in the cages, whereas non-treated fish often remained on the surface for some time, which in the wild may render 
them more vulnerable to predation. (Note that in this study, no estimate of the effects of predation or exposure upon survival rates of fish unable to return to depth was made). Thus, venting may still provide an advantage to fish suffering from barotrauma when they are released in the wild. Like lateral venting, buccal venting allowed swim bladder gases to escape but was easier to administer than lateral venting. In addition, there was less risk of inadvertently piercing internal organs. Further, no special tools or training were required, as the point of a clean sharp hook often, inadvertently, sufficed. Despite this, buccal venting has been the subject of very little research with possible effects of damage to the gut from eversion and piercing such as bleeding, infection and loss of osmoregulatory control theorised (Phelan 2008).

However, Burns (2009), in a laboratory experiment, reported that both Epinephelus morio (Val.) and Lutjanus campechanus (Poey) fed within 1-2 h of stomach prolapse and that dissections of wild-caught fish showed that whilst there was evidence of stomach prolapse, these fish fed normally and appeared healthy. A high proportion of pink snapper caught during the current study likely self-buccal vented by biting down on the everted stomach within the buccal cavity. For example, two fish that had not been buccal vented displayed scars on their stomachs of the same size and shape that were exhibited by buccal-vented fish, possible evidence of self-buccal venting from a previous capture. The high rate of healing over a short time period is further evidence of a lack of negative impacts from buccal venting on the survival of pink snapper. Although this method proved advantageous when treating pink snapper, buccal venting would only be appropriate for those species where stomach eversion is a likely symptom of barotrauma.

In a review of 274 studies assessing catch and release angling mortality, Bartholomew and Bohnsack (2005) estimated the average post-release survival across a wide range of species to be about $82 \%$. As such, at $88 \%$, pink snapper are relatively resilient to capture and subsequent discarding. In this study, there was no significant difference in survival as a function of capture depth or body size, contrasting results from previous studies where survival rates were estimated to be as low as $31 \%$ for pink snapper caught in shallower depths than in the present study (Stewart 2008; St John et al. 2009). These studies had much lower post-release survival rates of pink snapper associated with increased depths, ranging from 31 to $45 \%$ in depths ranging 45-65 m (Stewart 2008; St John et al. 2009). The current study assessed post-release survival for fish captured in depths ranging from 37 to $180 \mathrm{~m}$ with high rates of survival across all depths. In addition, the proportion of pink snapper exhibiting no barotrauma symptoms was not affected by water depth, with survival of these fish not differing significantly from treated fish.

Due to logistical considerations, the pink snapper captured from deeper water were kept in flow-through tanks on-board the research vessel for longer periods than those caught from the shallower depth class, which were transferred to the vertical enclosures within $1 \mathrm{~h}$. The GLM showed that this had no significant effect on postrelease survival, which was higher than in previous studies (Stewart 2008; St John et al. 2009). This suggests that the sealed cages used to hold captured fish in these previous studies may have been responsible for a high proportion of the mortalities reported by these authors. Brown et al. (2010) compared the survival of Lutjanus sebae (Cuvier) between the vertical sea enclosures as used in the current study to the smaller cages used by St John et al. (2009) and found that no L. sebae survived 3 days in the smaller, enclosed cages, whilst survival averaged $98 \%$ from the vertical sea enclosures. The lack of any significant difference in post-release survival between animals kept in the vertical enclosures in the current study and those kept on-board in flow-through systems may be evidence that caging pink snapper to assess their post-release survival is not necessary.

Comparatively, high healing rates of swim bladders observed within the 3-day study period are further evidence of the resilience of pink snapper to barotrauma. These findings are in accord with Butcher et al. (2012), who reported that there was no evidence of swim bladder rupture after 28 days in captivity. The higher healing rates $(45-50 \%)$ observed in swim bladders of fish captured from the deeper waters $(>50 \mathrm{~m})$ are in direct contrast to the much lower healing rates (19\%) for fish captured from shallower depths. This may be due to healed swim bladders rerupturing when pink snapper were retrieved from the $15-\mathrm{m}$ vertical enclosures at the end of each experiment. Not unexpectedly, larger ruptures were found to be less likely to have healed.

Many studies have identified deep hooking and bleeding as important factors affecting survival across a wide range of species (Bartholomew \& Bohnsack 2005; Alós et al. 2008; Mapleston et al. 2008; St John et al. 2009). As expected, this was also the case for pink snapper in the current study. However, the incidence of gut-hooking and/or heavy bleeding was rare using fishing gear representative of that used commonly in the fishery. This resulted in a relatively high post-release survival estimate for pink snapper during the current study. In conclusion, fish size and capture depth did not influence the postrelease survival of pink snapper and short-term survival across all depth classes was high. Buccal venting has been shown to be a viable alternative to lateral venting in pink snapper. It is easier to administer and requires 
no special tools or training but buccal venting cannot be advocated for other species until further studies confirm its more general efficacy and longer-term effects on survival.

\section{References}

Allen M., Sumpton W., O'Neill M., Courtney A.J. \& Pine B. (2006) Stochastic Stock Reduction Analysis for Assessment of the Pink Snapper (Pagrus Auratus) Fishery in Queensland. Brisbane, Qld: Department of Primary Industries and Fisheries, QI06069, $51 \mathrm{pp}$.

Alós J., Cerda M., Deudero S. \& Grau A.M. (2008) Influence of hook size and type on short-term mortality, hooking location and size selectivity in a Spanish recreational fishery. Journal of Applied Ichthyology 24, 658-663.

Bartholomew A. \& Bohnsack J.A. (2005) A review of catch-andrelease angling mortality with implications for no-take reserves. Reviews in Fish Biology and Fisheries 15, 129-154.

Bellgraph B.J., Brown R.S., Stephenson J.R., Welch A.E., Deters K.A. \& Clarlson T.J. (2008) Healing Rate of Swim Bladders in Rainbow Trout. Transactions of the American Fisheries Society 137, 1791-1794.

Broadhurst M.K., Gray C.A., Reid D.D., Wooden M.E.L., Young D.J., Haddy J.A. et al. (2005) Mortality of key fish species released by recreational anglers in an Australian estuary. Journal of Experimental Marine Biology and Ecology 321, 171-179.

Broadhurst M.K., Butcher P.A., Hall K.C., Cullis B.R. \& McGrath S.P. (2012) Resilience of inshore, juvenile snapper Pagrus auratus to angling and release. Journal of Fish Biology 80, 638-650.

Brown I., Sumpton W., McLennan M., Welch D., Kirkwood J., Butcher A. et al. (2008) National Strategy for the Survival of Release Line-Caught Fish: Tropical Reef Species. FRDC Final Report 2003/019. Brisbane, Qld: Queensland Department of Primary Industries and Fisheries, $182 \mathrm{pp}$.

Brown I.W., Sumpton W.D., McLennan M.F., Mayer D., Campbell M.J., Kirkwood J. et al. (2010) An improved technique for estimating short-term survival of released linecaught fish, and an application comparing barotrauma-relief methods in red emperor (Lutjanus sebae Cuvier 1816). Journal of Experimental Marine Biology and Ecology 385, $1-7$.

Burns K.M. (2009) J and Circle Hook Mortality and Barotrauma and the Consequences for Red Snapper Survival. SouthEast Data, Assessment, and Review, Stock Assessment Report, October 2010 (SEDAR24-RD47). Charleston, SC: National Oceanic and Atmospheric Administration, United States Department of Commerce, 77 pp.

Burns K.M. \& Restrepo V. (2002) Survival of Reef Fish After Rapid Depressurization: Field and Laboratory Studies, Vol. 30, National Symposium on Catch and Release in Marine Recreational Fisheries. Virginia Beach, VA: USA American Fisheries Society Symposium, 148-151.
Butcher P.A., Broadhurst M.K., Reynolds D., Reid D.D. \& Gray C.A. (2007) Release method and anatomical hook location: effects on short-term mortality of angler-caught Acanthopagrus australis and Argyrosomus japonicus. Diseases of Aquatic Organisms 74, 17-26.

Butcher P.A., Broadhurst M.K. \& Cairns S.C. (2008) Mortality and physical damage of angled-and-released dusky flathead Platycephalus fuscus. Diseases of Aquatic Organisms 81, 127134.

Butcher P.A., Broadhurst M.K., Hall K.C., Cullis B.R. \& Raidal S.R. (2012) Assessing barotrauma among angled snapper (Pagrus auratus) and the utility of release methods. Fisheries Research 127-128, 49-55.

Campana S.E., Joyce W., Francis M.P. \& Manning M.J. (2009) Comparability of blue shark mortality estimates for the Atlantic and Pacific longline fisheries. Marine Ecology Progress Series 396, 161-164.

Campbell A., O'Neill M., Sumpton W., Kirkwood J. \& Wesche S. (2009) Stock Assessment of the Queensland Snapper Fishery (Australia) and Management Strategies for Improving Sustainability. Brisbane, Qld: Queensland Primary Industries and Fisheries, Department of Employment, Economic Development and Innovation, $86 \mathrm{pp}$.

Campbell M.J., McLennan M.F. \& Sumpton W.D. (2014) Shortterm survival of discarded pearl perch (Glaucosoma scapulare, Ramsay, 1881) caught by hook-and-line in Queensland, Austalia. Fisheries Research 150, 206-212.

Collins M.R., McGovern J.C., Sedberry G.R., Meister H.S. \& Pardieck R. (1999) Swim bladder deflation in Black Sea bass and vermilion snapper: potential for increasing postrelease survival. North American Journal of Fisheries Management 19, 828-832.

Cooke S.J. \& Schramm H.L. (2007) Catch-and-release science and its application to conservation and management of recreational fisheries. Fisheries Management and Ecology 14, $73-79$.

Cooke S.J., Suski C.D., Barthel B.L., Ostrand K.G., Tufts B.L. \& Philipp D.P. (2003) Injury and mortality induced by four hook types on bluegill and pumpkinseed. North American Journal of Fisheries Management 23, 883-893.

Danylchuk A.J., Danylchuk S.E., Cooke S.J., Goldberg T.L., Koppelman J.B. \& Philipp D.P. (2007) Post-release mortality of bonefish, Albula vulpes, exposed to different handling practices during catch-and-release angling in Eleuthera, The Bahamas. Fisheries Management and Ecology 14, 149-154.

Ferter K., Weltersbach M.S., Strehlow H.V., Vølstad J.H., Alós J., Arlinghaus R. et al. (2013) Unexpectedly high catch-andrelease rates in European marine recreational fisheries: implications for science and management. ICES Journal of Marine Science: Journal du Conseil 70, 1319-1329.

Florida Sea Grant (2005) A Guide to Releasing Reef Fish With Ruptured Swim Bladders. Gainesville, FL: FSG, FLSGP-H-99004, SGEF-46, 2 pp.

GenStat (2011) Version 11, 11th edn. Hemel Hempstead: VSN International Ltd. 
Grixti D., Conron S.D. \& Morison A. (2010) Post-release survival of recreationally caught snapper, Pagrus auratus, in Port Phillip Bay, south-eastern Australia. Fisheries Management and Ecology 17, 1-9.

Higgs J. (1999) Experimental Recreational Catch Estimates for Queensland Residents. Results from the 1997 diary round. RFISH Technical Report No. 2. Brisbane, Qld: Queensland Fisheries Service, 55 pp.

Higgs J. (2001) Recreational Catch Estimates for Queensland Residents. Results from the 1999 diary round. RFISH Technical Report No. 3. Brisbane, Qld: Queensland Fisheries Service, 62 pp.

Hochhalter S.J. \& Reed D.J. (2011) The Effectiveness of Deepwater Release at Improving the Survival of Discarded Yelloweye Rockfish. North American Journal of Fisheries Management 31, 852-860.

Humborstad O.-B. \& Mangor-Jensen A. (2013) Buoyancy adjustment after swimbladder puncture in cod Gadus morhua: an experimental study on the effect of rapid decompression in capture-based aquaculture. Marine Biology Research 9, 383393.

Kerr S.J. (2001) A Review of "Fizzing" a Technique for Swim Bladder Deflation. Peterborough, ON: Ministry of Natural Resources, Fisheries Section, 12 pp.

Mapleston A., Welch D., Begg G.A., McLennan M.F., Mayer D. \& Brown I.W. (2008) Effect of changes in hook pattern and size on catch rate, hooking location, injury and bleeding for a number of tropical reef fish species. Fisheries Research 91, 203-211.

McGrath S.P., Broadhurst M.K., Butcher P.A. \& Cairns S.C. (2011) Fate of three Australian teleosts after ingesting conventional and modified stainless- and carbon-steel hooks. ICES Journal of Marine Science: Journal du Conseil 68, 2114-2122.

McInnes K. (2006) 2004 Biennial Recreational Fishing Telephone Survey of Queensland Residents. Brisbane, Qld: Queensland Department of Primary Industries and Fisheries, $72 \mathrm{pp}$.

McInnes K. (2008) Experimental Results From the Fourth Queensland Recreational Fishing Diary Program (2005). Brisbane, Qld: Queensland Deparment of Primary Industries and Fisheries, $34 \mathrm{pp}$.

McLeay L.J., Jones G.K. \& Ward T.M. (2002) National Strategy for the Survival of Released Line-Caught Fish: A Review of Research and Fishery Information. Final Report to FRDC on Project No. 2001/101. Henley Beach: South Australian Research and Development Institute (SARDI), 122 pp.
Midling K.Ø., Koren C., Humborstad O.-B. \& Sæther B.-S. (2012) Swimbladder healing in Atlantic cod (Gadus morhua), after decompression and rupture in capture-based aquaculture. Marine Biology Research 8, 373-379.

National Marine Fisheries Service (2013) Catch and Release Best Practices. Available at: http://www.nmfs.noaa.gov/sfa/manage ment/recreational/documents/catch_release_web.pdf (accessed 20 May 2013).

Nichol D.G. \& Chilton E.A. (2006) Recuperation and behaviour of Pacific cod after barotrauma. ICES Journal of Marine Science: Journal du Conseil 63, 83-94.

Phelan M. (2008) Assessment of the Implications of Target Fishing on Black Jewfish (Protonibea Diacanthus) Aggregations in Northern Territory. Darwin: Fishery report Northern Territory: Department of Primary Industry, Fisheries and Mines, 91, 103, pp.

Recfishing Australia (2013) Best Practices in Recreational Fishing. Available at: http://recfishingresearch.org/best-practicesin-recreational-fishing/ (accessed 20 May 2013).

Shasteen S.P. \& Sheehan R.J. (1997) Laboratory evaluation of artificial swim bladder deflation in largemouth bass: potential benefits for catch-and-release fisheries. North American Journal of Fisheries Management 17, 32-37.

St John J. \& Syers C.J. (2005) Mortality of the demersal West Australian dhufish, Glaucosoma hebraicum (Richardson 1845) following catch and release: the influence of capture depth, venting and hook type. Fisheries Research 76, 106-116.

St John J., Syers C.\& Craine M. (2009) The influence of depth, venting and hook type on catch and release angling mortality of snapper, Pagrus auratus (Sparidae): implications for management. In: R. Lenanton, B. Wise, J. St John, I. Keay \& D. Gaughan (eds) Maximising Survival of Released Undersize West Coast Reef Fish. North Beach, WA: Department of Fisheries, Western Australia. Final FRDC Report Project 2000/ 194, $130 \mathrm{pp}$.

Stewart J. (2008) Capture depth related mortality of discarded snapper (Pagrus auratus) and implications for management. Fisheries Research 90, 289-295.

Sumpton W.D., Sawynok B. \& Carstens N. (2003) Localised movement of snapper (Pagrus auratus, Sparidae) in a large subtropical marine embayment. Marine and Freshwater Research 54, 923-930.

Wilde G.R. (2009) Does venting promote survival of released fish? Fisheries 34, 20-28.

Wilde G.R. \& Sawynok W. (2009) Effect of hook removal on recapture rates of 27 species of angler-caught fish in Australia. Transactions of the American Fisheries Society 138, 692-697. 